\title{
Non-fatal work related injuries in a cohort of Brazilian steelworkers
}

\author{
Minouk J Schoemaker, Sandhi M Barreto, Anthony J Swerdlow, Craig D Higgins, \\ Robert G Carpenter
}

\begin{abstract}
Objectives-Workers in the steel industry are exposed to various severe hazards. This study investigated risk factors for non-fatal injury occurring in the workplace and during travel to and from work in steelworkers in Brazil.

Methods-Non-fatal work related injuries during employment from January 1977 to September 1992 were analysed in a cohort of 21732 male workers in the steel plant of USIMINAS, Brazil.
\end{abstract}

Results-There were 14972 non-fatal injuries during follow up, with 10891 injuries in the workplace and 4081 during travel to and from work (travel to work injury). The rate of injury in the workplace was 5.6/100 person-years and that of travel to work injury was $2.1 / 100$ personyears. The most common injuries were to hands, arms, and eyes, with $90 \%$ of the eye injuries caused by a foreign body. Both rates of workplace and travel to work injury increased significantly with the number of injuries previously experienced, and decreased with number of years in employment and calendar period. The rates of travel to work injury also seemed to decrease with age, but age was not an independent predictor of workplace injury when we controlled for duration of employment. The rate of workplace injury was increased eightfold for workers who had experienced more than six previous injuries compared with those with no previous workplace injuries after adjusting for duration of employment and calendar period. Labourers were most at risk of workplace injury, with about eight injuries per 100 person-years. Travel to work injury was most common among support workers, with nearly half of the travel to work injuries affecting the eyes.

Conclusion-The rate of injury was high in these steelworks, both for workplace and travel to work injuries. Characteristics of the work areas and the employees can identify high risk groups; protective measures, safety, health training, and injury programmes should concentrate particularly on these groups. Prevention of eye injury needs special attention in steelworks.

(Occup Environ Med 2000;57:555-562)

Keywords: steel workers; injuries

Injury is a major cause of death among young people and a significant contributor to the glo- bal burden of disease and disability, accounting for $10 \%$ of mortality and $15 \%$ of the burden of death and disability world wide in 1990 (as expressed in disability adjusted life-years). ${ }^{1}$ In most developed countries injury ranks third among the causes of death in men and women, whereas in developing countries it ranks third in men and fourth in women. ${ }^{2}$ In the United States, the National Safety Council $(1998)^{3}$ estimated that 3.8 million work related unintentional disabling injuries occurred in 1997, with a total cost of $\$ 127.7$ billion. The burden is particularly large in Latin America. ${ }^{4}$ In Brazil, injury is responsible for about $60 \%$ of the deaths among men aged $15-44 .^{5}$

Occupation has been estimated to account for nearly one fifth of the global burden of injury, ${ }^{4}$ but estimates of the burden of occupational injury are often imprecise because of underreporting and classification problems. Although a substantial amount is known about risk factors for the relatively few injury deaths, there is less information about hospital inpatient cases and still less about cases resulting in neither death nor hospital admission. Recent studies have reported on non-fatal injury in occupational groups including workers in the automotive manufacturing industry, ${ }^{6}$ the furniture industry, ${ }^{7}$ construction workers, ${ }^{8} 9$ electrical utility meter readers, ${ }^{10}$ and petroleum drilling workers. ${ }^{11}$ Non-fatal injuries during travel to and from work have received even less attention than non-fatal injuries in the workplace.

The present study reports on non-fatal work related injury in a large cohort of workers in a Brazilian steel manufacturing plant. Steelworkers represent one of the largest occupational groups in Brazil. Although steelworks have long been regarded as hazardous places to work, ${ }^{12-14}$ with exposure to hazards such as heat, noise, vibration, and gases, little published information is available from analytical epidemiological studies on injuries related to work areas and occupational hazards. Several studies of steelworkers in developed countries have reported the risk of death from injuries, ${ }^{13-17}$ but there are few reports on non-fatal injuries. A study in Mexico described disabling injuries and a study in India examined burn injuries in the steel industry, ${ }^{14}{ }^{18}$ but these studies were small. However, to our knowledge, no other substantially sized studies have reported on injuries among steelworkers in the developing world.

The present paper describes the occurrence and risk factors for non-fatal work related injuries based on over 14000 injuries in a cohort of 21732 Brazilian steelworkers for whom we have previously reported on mortality. ${ }^{19-21}$ 
Table 1 Type of injury (n) and part of the body affected by injury for workplace injuries

\begin{tabular}{|c|c|c|c|c|c|c|c|c|}
\hline \multirow[b]{2}{*}{ Type of injury } & \multicolumn{8}{|c|}{ Part of body affected } \\
\hline & Eyes & $\begin{array}{l}\text { Face } \\
\text { or ear }\end{array}$ & $\begin{array}{l}\text { Hands } \\
\text { or arms }\end{array}$ & $\begin{array}{l}\text { Feet } \\
\text { or leg }\end{array}$ & Back & $\begin{array}{l}\text { Multiple } \\
\text { sites }\end{array}$ & Other & Total \\
\hline Laceration or scraping & 6 & 319 & 2433 & 434 & 50 & 75 & 115 & 3432 \\
\hline $\begin{array}{l}\text { Contusion or } \\
\text { smashing }\end{array}$ & 24 & 61 & 1050 & 580 & 145 & 77 & 163 & 2100 \\
\hline Foreign body & 1772 & 13 & 60 & 16 & 3 & 1 & 16 & 1881 \\
\hline Burn & 67 & 76 & 524 & 201 & 20 & 148 & 44 & 1080 \\
\hline Sprain & & 3 & 62 & 306 & 414 & 1 & 24 & 810 \\
\hline Fracture & & 20 & 354 & 137 & 14 & 5 & 5 & 535 \\
\hline Poisoning & & & & & & 1 & 215 & 216 \\
\hline Puncture & 1 & 5 & 49 & 51 & 1 & & 3 & 110 \\
\hline Excessive light & 107 & & & & & & & 107 \\
\hline $\begin{array}{l}\text { Chemical } \\
\text { conjunctivitis }\end{array}$ & 104 & & & & & & & 104 \\
\hline Chemical burn & 12 & 14 & 28 & 10 & 5 & 20 & 4 & 93 \\
\hline Scald & & 6 & 26 & 22 & 2 & 19 & 5 & 80 \\
\hline Amputation & & & 37 & 8 & & 1 & & 46 \\
\hline Electrical shock & & & & & & 3 & 18 & 21 \\
\hline Other & 1 & 13 & 74 & 41 & 4 & 91 & 50 & 274 \\
\hline Not known & & & & & 1 & & 1 & 2 \\
\hline Total & 2094 & 530 & 4697 & 1806 & 659 & 442 & 663 & 10891 \\
\hline
\end{tabular}

Table 2 Type of injury (n) and part of the body affected by injury for travel to work injuries

\begin{tabular}{|c|c|c|c|c|c|c|c|}
\hline \multirow[b]{2}{*}{ Type of injury } & \multicolumn{7}{|c|}{ Part of body affected } \\
\hline & Eyes & $\begin{array}{l}\text { Face or } \\
\text { ear }\end{array}$ & $\begin{array}{l}\text { Hands or } \\
\text { arms }\end{array}$ & $\begin{array}{l}\text { Feet or } \\
\text { leg }\end{array}$ & $\begin{array}{l}\text { Multiple } \\
\text { sites }\end{array}$ & Other & Total \\
\hline Foreign body & 1908 & 3 & 2 & 1 & & & 1914 \\
\hline Laceration or scraping & 4 & 99 & 229 & 148 & 310 & 45 & 835 \\
\hline Contusion or smashing & 4 & 18 & 166 & 215 & 116 & 142 & 661 \\
\hline Sprain & & & 24 & 180 & & 40 & 244 \\
\hline Fracture & & 8 & 71 & 59 & 10 & 15 & 163 \\
\hline Multiple types & & 5 & 13 & 17 & 157 & 10 & 202 \\
\hline Other & 5 & 2 & 5 & 14 & 5 & 31 & 62 \\
\hline Total & 1921 & 135 & 510 & 634 & 598 & 283 & 4081 \\
\hline
\end{tabular}

Methods

The cohort comprised all male workers at the USIMINAS steel plant in Minas Gerais, Brazil who were employed at any time between 1 January 1977 and 31 August 1990. Workers who started employment before 1977 entered the study on 1 January 1977. Workers who started later entered the study on their first day of employment at the plant. Follow up finished with end of employment at the plant, death, or 15 September 1992, whichever occurred ear-

Table 3 Risk factors for injuries in the workplace

\begin{tabular}{|c|c|c|c|c|}
\hline Factor & $\begin{array}{l}\text { Injuries } \\
\text { (n) }\end{array}$ & Person-years & $\begin{array}{l}\text { Rate/100 } \\
\text { person-years }\end{array}$ & Adjusted rate ratio $*(95 \%$ CI $)$ \\
\hline \multicolumn{5}{|c|}{ Age group (y): } \\
\hline$<20$ & 891 & 7084 & 12.6 & 1.00 \\
\hline $20-24$ & 3240 & 35003 & 9.3 & $0.76(0.70$ to 0.83$)$ \\
\hline $25-29$ & 2799 & 44958 & 6.2 & $0.61(0.56$ to 0.66$)$ \\
\hline $30-34$ & 1780 & 42197 & 4.2 & $0.51(0.46$ to 0.55$)$ \\
\hline $35-39$ & 1043 & 30358 & 3.4 & $0.42(0.38$ to 0.47$)$ \\
\hline $40-44$ & 628 & 18438 & 3.4 & $0.40(0.36$ to 0.45$)$ \\
\hline$\geqslant 45$ & 510 & 16183 & 3.2 & $\begin{array}{l}0.35(0.31 \text { to } 0.40) \\
\chi_{1}^{2} \text { trend }=715, \mathrm{p}<0.0001\end{array}$ \\
\hline \multicolumn{5}{|c|}{ Duration of employment (y): } \\
\hline$<1$ & 1547 & 11281 & 13.7 & 1.00 \\
\hline $1-1.9$ & 1400 & 11947 & 11.7 & $0.89(0.82$ to 0.95$)$ \\
\hline $2-4.9$ & 3278 & 37394 & 8.8 & $0.72(0.67$ to 0.76$)$ \\
\hline $5-9.9$ & 2346 & 52528 & 4.5 & $0.47(0.44$ to 0.51$)$ \\
\hline $10-14.9$ & 1293 & 42853 & 3.0 & $0.39(0.36$ to 0.42$)$ \\
\hline$\geqslant 15$ & 1027 & 38218 & 2.7 & $\begin{array}{l}0.30(0.27 \text { to } 0.33) \\
\chi_{1}^{2} \text { trend }=1192, \mathrm{p}<0.0001\end{array}$ \\
\hline \multicolumn{5}{|c|}{ Calendar period: } \\
\hline $1977-80$ & 5636 & 49174 & 11.5 & 1.00 \\
\hline $1981-84$ & 2538 & 51965 & 4.9 & $0.53(0.51$ to 0.56$)$ \\
\hline $1985-88$ & 1671 & 50526 & 3.3 & $0.40(0.38$ to 0.43$)$ \\
\hline $1989-92$ & 1046 & 42557 & 2.5 & $\begin{array}{l}0.33(0.30 \text { to } 0.35) \\
\chi_{1}^{2} \text { trend }=1524, \mathrm{p}<0.0001\end{array}$ \\
\hline Total & 10891 & 194222 & 5.6 & \\
\hline
\end{tabular}

*Age group and duration of employment are adjusted for calendar period and calendar period is adjusted for duration of employment. lier. The subjects in the cohort were identified from records in the personnel department. The total number of workers was 21870 , but essential data were missing or incomplete for 138 workers, resulting in 21732 men in the present study. The methods of data collection have been described previously. ${ }^{19}$

This study investigated two types of injury; workplace injury that occurred inside the plant during the work shift and injury that occurred during travel to and from work (travel to work injury). The injuries were ascertained by a team under the supervision of SMB with the database of the Occupational Hygiene Department, which contained information on date and site of injury, type of tissue damage, number of working days lost as a result of the injury, and other general information about the worker. Information on injury was recorded on a card on the day that the injury occurred. Workers were followed up until completion of the information on number of workdays lost and possible long term consequences of the injury. Site and type of injury were also recorded at the time of injury with standard labels and entered into a computer file as recorded on the card. This database was thought to be highly complete because of the steelworks' highly organised occupational health and hygiene sectors that were responsible for processing and storing information promptly and submitting injury information to the Ministry of Labour monthly.

Information on the number of hours worked on a yearly basis was not available for individual workers. As an alternative to number of hours worked, we calculated injury rates with the number of person-years in employment as the denominator. Injury rates per 100 person-years at risk were calculated. Stata statistical software was used for the analysis. ${ }^{22}$ Rate ratios were obtained by Poisson regression, with the $95 \%$ confidence intervals (95\% CIs) based on Huber-White robust estimates of the SEM. ${ }^{23}$ These SEMs were used to correct for a potential underestimation of the SEM due to the fact that many workers had several injuries and therefore that not all observations were independent. The Huber SEMs were confirmed with bootstrap analysis that showed very similar results. Rates were calculated by age group, number of years in employment, calendar period, job category, and place of work. Multiple regression analysis was undertaken to obtain rate ratios adjusted for confounding factors. In the multiple regression model, simultaneous adjustment for age and duration of employment was not possible because of strong collinearity. Therefore, for each model that was fitted, it was determined whether age or duration of employment was a stronger predictor of the outcome, on the basis of log likelihood ratio tests. For workplace injuries it was evident that duration of employment was a better predictor than age. For travel to work injuries they were equally strong predictors in the separate models with calendar period, job category, place of work, or injury history whereas duration of employment was a better predictor in the model with all four other 
Table 4 Risk factors for injuries during travel to and from work

\begin{tabular}{|c|c|c|c|c|}
\hline Factor & $\begin{array}{l}\text { Injuries } \\
\text { (n) }\end{array}$ & Person-years & $\begin{array}{l}\text { Rate } 100 \\
\text { person-years }\end{array}$ & Adjusted rate ratio $*(95 \%$ CI $)$ \\
\hline \multicolumn{5}{|c|}{ Age group (y): } \\
\hline$<20$ & 305 & 7084 & 4.3 & 1.00 \\
\hline $20-24$ & 1206 & 35003 & 3.5 & $0.84(0.74$ to 0.95$)$ \\
\hline $25-29$ & 1046 & 44958 & 2.3 & $0.65(0.57$ to 0.74$)$ \\
\hline $30-34$ & 686 & 42197 & 1.6 & $0.53(0.46$ to 0.62$)$ \\
\hline $35-39$ & 395 & 30358 & 1.3 & $0.44(0.38$ to 0.52$)$ \\
\hline $40-44$ & 223 & 18438 & 1.2 & 0.40 (0.33 to 0.48$)$ \\
\hline$\geqslant 45$ & 220 & 16183 & 1.4 & $0.43(0.35$ to 0.51$)$ \\
\hline & & & & $\chi_{1}^{2}$ trend $=244, p<0.0001$ \\
\hline \multicolumn{5}{|c|}{ Duration of employment (y): } \\
\hline$<1$ & 463 & 11281 & 4.1 & 1.00 \\
\hline $1-1.9$ & 474 & 11947 & 4.0 & $1.00(0.88$ to 1.14$)$ \\
\hline $2-4.9$ & 1203 & 37394 & 3.2 & $0.89(0.80$ to 0.99$)$ \\
\hline $5-9.9$ & 964 & 52528 & 1.8 & $0.62(0.55$ to 0.70$)$ \\
\hline $10-14.9$ & 522 & 42853 & 1.2 & $0.48(0.42$ to 0.56$)$ \\
\hline$\geqslant 15$ & 455 & 38218 & 1.2 & $0.43(0.38$ to 0.50$)$ \\
\hline & & & & $\chi_{1}^{2}$ trend $=286, p<0.0001$ \\
\hline \multicolumn{5}{|c|}{ Calendar period: } \\
\hline $1977-80$ & 1948 & 49174 & 4.0 & \multirow{6}{*}{$\begin{array}{l}1.00 \\
0.54(0.49 \text { to } 0.59) \\
0.51(0.46 \text { to } 0.56) \\
0.35(0.31 \text { to } 0.39) \\
\chi_{1}^{2} \text { trend }=435, \mathrm{p}<0.0001\end{array}$} \\
\hline $1981-84$ & 947 & 51965 & 1.8 & \\
\hline $1985-88$ & 775 & 50526 & 1.5 & \\
\hline 1989-92 & 411 & 42557 & 1.0 & \\
\hline & & & & \\
\hline Total & 4081 & 194222 & 2.1 & \\
\hline
\end{tabular}

^Age group and duration of employment are adjusted for calendar period and calendar period is adjusted for duration of employment.

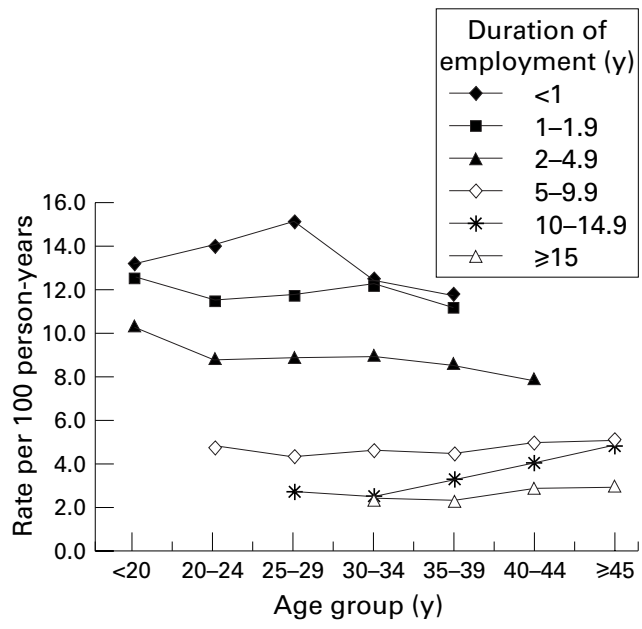

Rates of workplace injury by age group within categories of duration of employment.

predictor variables. Therefore, we decided to adjust the effect of calendar period, job category, place of work or injury history on workplace and travel to work injury for duration of employment. We recalculated the rate ratios for travel to work injury after adjustment for age for comparative purposes.

The $\chi^{2}$ tests for heterogeneity of adjusted rate ratios were carried out by comparing the deviance of the model including the categorical variable with a model without this variable. The difference in deviance between the two models was then compared with a $\chi^{2}$ distribution with the degrees of freedom equal to the number of parameters of this variable. The $\chi^{2}$ tests for trend were done by comparing the deviance of the model with the predictor variable fitted as scores and the model without this variable.

Because we did not have information on injuries before 1 January 1977, and because job category and place of work were known only at the start of employment and end of follow up, not at the time of injury, we had to conduct analyses of rates relative to number of previous injuries, job category, and place of work at the time of injury for a subset of workers for whom this was known. Therefore we analysed rates relative to injury history for workers who started employment on or after 1 January 1977 and rates relative to job category and place of work for workers who had the same job category and place of work at the start of employment and end of follow up. We assumed that these workers did not temporarily change job category or place of work in the interim. The joint effect of duration of employment, calendar period, injury history, job category, and work area could only be assessed for workers who started employment on or after 1 January 1977 and who had the same job category and place of work at the start of employment and end of follow up.

\section{Results}

The cohort consisted of 21732 workers, most $(75 \%)$ of whom entered the study before the age of 28. Half of the cohort (10 768) entered the study on 1 January 1977 and the rest entered later. At the end of the study period, 15 September 1992, 8834 workers were still current employees and hence still under follow up.

Most of the workers entered employment as labourers $(65.7 \%)$ or support workers (20.8\%). Support workers are workers involved in various tasks - such as administrative duties, stock and supply, cooking, cleaning operations, and construction. Labourers were mainly recruited for the plate mill, steel mill and foundry, coke oven and blast furnace, and maintenance units.

More than two thirds of men recruited as support workers changed job category, mostly to labourer or technician, during the course of employment. The remaining $31 \%$ of workers were still classified as support worker at the end of follow up. Workers who were recruited to the plant as labourers, professionals, and technicians usually remained classified in these job categories until the end of follow up.

A total of 14972 non-fatal injuries occurred during the follow up period, $10891(72.7 \%)$ in the workplace and $4081(27.3 \%)$ on the way to or from work. There were 7920 workers who had an injury during the study of whom 4244 had one injury and 3676 had more than one. Fifty one injuries resulted in permanent disability, $86 \%$ of them being amputations, otherwise continuing employment did not seem to be strongly influenced by injury as only $85(1.1 \%)$ injuries were followed by leaving employment within 2 months. There were 37 fatal work related injuries, on which we have reported previously. ${ }^{19}$

Laceration and scraping, contusion and smashing, penetration of a foreign body, and burns were the types of injury most often found in the workplace. The hands, arms, and eyes were most often affected (table 1). The most common types of travel to work injury were penetration by a foreign body, laceration and scraping, and contusion and smashing (table $2)$. Nearly half $(47.1 \%)$ of these injuries 
Table 5 Rate of workplace and travel to work injury by job category and place of work, for workers who were classified in the same job category and place of work at the start and end of follow up $(n=13668)$

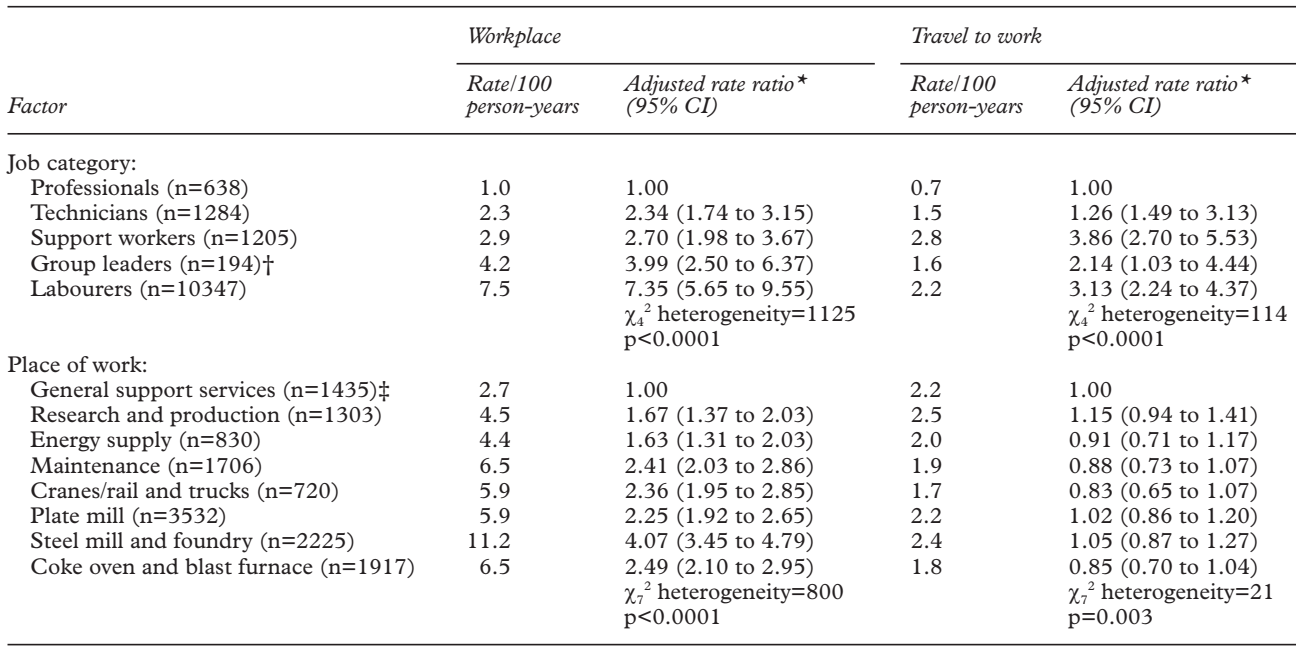

*Adjusted for calendar period and duration of employment.

†Group leaders are skilled workers who supervise a group of labourers in the production process.

$\ddagger$ Includes administration and support, stock and supply, and construction work.

affected the eyes. A foreign body was the cause of eye injury in $84.5 \%$ of the eye injuries in the workplace and $99.3 \%$ of the eye injuries that were related to travel to work. The remaining travel to work injuries often were lacerations and scrapings, contusions and smashings and sprains (tables 1 and 2).

One thousand and seventeen $(6.8 \%$ of the total) injuries resulted in loss of one or more working days. The median number of working days lost for these injuries was 30 days. Lost working days were most common among labourers, with 53.7 lost working days per 100 person-years, whereas they were over a thousand times less common among professionals $(0.02 / 100$ person-years). Injuries with lost working days were most common in workers at the plate mill, steel mill and foundry, and at the coke oven and blast furnace, with 66.1, 52.4, and 48.7 lost working days per 100 personyears, respectively.

Both workplace and travel to work injury showed a highly significant decreased rate with age of the worker, number of years in employment, and calendar period (tables 3 and 4). However, when the effect of age was examined within categories of duration of employment, the rate of workplace injury within each category was constant, whereas large and consistent differences in rate of injury between these employment categories remained within each age group (figure). For travel to work injuries, the effect of age and duration of employment could not be easily disentangled.

Even after adjusting for calendar period, the rate of travel to work injury was more than twice as high and that of workplace injury was more than three times higher among newly employed workers than in workers employed for more than 15 years.

Labourers were most at risk of workplace injuries (table 5), with an overall rate of injuries of 7.5/100 person-years. The highest injury rate was found among labourers in the steel mill (12.3/100 person-years) and group leaders in the cranes, rail, and trucks unit (14.1/100 person-years), but this was based on small numbers (data not shown).

Differences in injury rate between job categories were also found for travel to work injury, with the highest rates among support workers and labourers and the lowest among professionals.

There was considerable variation in the rate of workplace injury between work units (table 5). Workplace injury was most common in the steel mill and foundry, and the coke oven and blast furnace area; the maintenance unit, the plate mill and the cranes, rail, and trucks unit were also relatively hazardous. The rate of travel to work injury also varied highly significantly across places of work; injury was most frequent among workers in the steel mill and foundry, the research and production unit, the general support services unit, and the plate mill.

The rates of workplace and travel to work injuries were found to increase with the number of previous injuries (table 6). Compared with those with no previous injury, the rate of workplace injury increased twofold after three and four injuries and over threefold after six or more injuries. After adjustment for duration of employment and calendar period, these rate ratios were roughly doubled. For travel to work injury, the adjusted rate was three times higher in workers with three or more injuries compared with workers with no previous travel to work injury.

Duration of employment, injury history, calendar period, job category, and work area remained strong predictors for both workplace and travel to work injury in the 7793 workers who started employment on or after 1 January 1977 and who were classified in the same job category and place of work at the start and end of follow up (table 7).

The rate ratios of calendar period, job category, place of work, and injury history for travel to work injury were nearly identical when adjusted for age instead of duration of employment in all investigated subgroups of workers. 
Table 6 Rate of injury relative to the number of previous injuries experienced, for workers recruited 1 fanuary 1977 or later $(n=10963)$

\begin{tabular}{|c|c|c|c|c|}
\hline $\begin{array}{l}\text { Previous injuries of this } \\
\text { type experienced }(n)\end{array}$ & $\begin{array}{l}\text { Injuries * } \\
(n)\end{array}$ & Person-years & $\begin{array}{l}\text { Rate/100 } \\
\text { person-years }\end{array}$ & $\begin{array}{l}\text { Adjusted rate ratiof } \\
(95 \% \mathrm{CI})\end{array}$ \\
\hline \multicolumn{5}{|l|}{ Injury in the workplace } \\
\hline 0 & 3074 & 57406 & 5.4 & 1.00 \\
\hline 1 & 1168 & 16431 & 7.1 & $1.89(1.76$ to 2.03$)$ \\
\hline 2 & 443 & 5617 & 7.9 & 2.63 (2.36 to 2.93$)$ \\
\hline 3 & 191 & 1764 & 10.8 & 4.03 (3.44 to 4.72$)$ \\
\hline 4 & 82 & 761 & 10.8 & 4.13 (3.27 to 5.22$)$ \\
\hline 5 & 35 & 330 & 10.6 & 4.27 (3.09 to 5.89$)$ \\
\hline$\geqslant 6$ & 39 & 212 & 18.4 & $\begin{array}{l}8.13(5.92 \text { to } 11.19) \\
\chi_{1}^{2} \text { trend }=707, \mathrm{p}<0.0001\end{array}$ \\
\hline \multicolumn{5}{|c|}{ Injury during travel to work: } \\
\hline 0 & 1457 & 71567 & 2.0 & 1.00 \\
\hline 1 & 274 & 9127 & 3.0 & $2.15(1.81$ to 2.56$)$ \\
\hline 2 & 40 & 1543 & 2.6 & 2.37 ( 1.58 to 3.56$)$ \\
\hline$\geqslant 3$ & 11 & 285 & 3.9 & $3.24(1.59$ to 6.59$)$ \\
\hline
\end{tabular}

*Number of observed workplace injuries and travel to work injuries, respectively. †Adjusted for duration of employment and calendar period.

Because nearly half of the travel to work injuries affected the eyes, we analysed eye injuries and non-eye injuries separately. The rate of injury to the eye during travel to work decreased significantly with age, duration of employment, and calendar period (data not shown). More than two thirds (69\%) of these eye injuries occurred before 1983 when the emissions of the plant, which often contained small fragments of steel, started to be filtered. The decrease in rate of eye injuries was most pronounced over the period when filtering was introduced: the rate ratio for this injury during 1981-4 compared with $1977-80$ was 0.39 (95\% CI 0.34 to 0.44 ), after adjusting for duration of employment; the rate continued to decrease, although less steeply, subsequently. Support workers and labourers had the highest rates, with adjusted rate ratios compared with professionals of 2.35 (95\% CI 1.53 to 3.62 ) and 1.81 (95\% CI 1.23 to 2.66 ) respectively.

Travel to work injuries that did not affect the eyes also showed significant trends with age, duration of employment, and with calendar period; the injury rate roughly halved from 1977-80 to 1989-92. All job categories had highly increased adjusted rate ratios compared with professionals, in particular labourers (16.19; $95 \%$ CI 7.27 to 36.09$)$ and support workers (12.44; 95\% CI 5.32 to 29.06 ).

Table 7 Risk factors for workplace and travel to work injuries, for workers who were recruited after 1 fanuary 1977 and who were classified in the same job category and place of work at the start and end of follow up $(n=7793)$

\begin{tabular}{|c|c|c|c|c|c|}
\hline \multirow[b]{2}{*}{ Factor } & \multirow[b]{2}{*}{$\begin{array}{l}\text { Person- } \\
\text { years }\end{array}$} & \multicolumn{2}{|l|}{ Workplace } & \multicolumn{2}{|l|}{ Travel to work } \\
\hline & & $\begin{array}{l}\text { Rate/100 } \\
\text { Person-years }\end{array}$ & $\begin{array}{l}\text { Adjusted rate ratio* } \\
(95 \% \mathrm{CI})\end{array}$ & $\begin{array}{l}\text { Rate/100 } \\
\text { Person-years }\end{array}$ & $\begin{array}{l}\text { Adjusted rate ratio* } \\
(95 \% \mathrm{CI})\end{array}$ \\
\hline \multicolumn{6}{|l|}{ Duration of employment (y): } \\
\hline$<1$ & 7099 & 12.9 & 1.00 & 3.5 & 1.00 \\
\hline $1-1.9$ & 6158 & 10.1 & 0.77 (0.70 to 0.85$)$ & 3.1 & $0.91(0.76$ to 1.10$)$ \\
\hline $2-4.9$ & 14994 & 6.5 & $0.53(0.48$ to 0.60$)$ & 2.2 & 0.77 (0.64 to 0.92$)$ \\
\hline $5-9.9$ & 16083 & 3.5 & $0.30(0.27$ to 0.35$)$ & 1.4 & $0.48(0.38$ to 0.60$)$ \\
\hline$\geqslant 10$ & 9463 & 2.9 & $\begin{array}{l}0.28(0.23 \text { to } 0.33) \\
\chi_{1}^{2} \text { trend }=243, p<0.0001\end{array}$ & 0.9 & $\begin{array}{l}0.38(0.28 \text { to } 0.51) \\
\chi_{1}^{2} \text { trend }=56, p<0.0001\end{array}$ \\
\hline \multicolumn{6}{|c|}{ Previous workplace injuries (n): } \\
\hline 0 & 37351 & 5.3 & 1.00 & & \\
\hline 1 & 10512 & 7.5 & 1.76 (1.61 to 1.92$)$ & & \\
\hline 2 & 3822 & 8.2 & $2.23(1.96$ to 2.54$)$ & & \\
\hline 3 & 1186 & 12.0 & $3.50(2.92$ to 4.20$)$ & & \\
\hline 4 & 517 & 11.8 & $3.34(2.54$ to 4.39$)$ & & \\
\hline 5 & 249 & 10.9 & $3.30(2.27$ to 4.80$)$ & & \\
\hline$\geqslant 6$ & 161 & 19.3 & $\begin{array}{l}5.22(3.61 \text { to } 7.55) \\
\chi_{1}^{2} \text { trend }=344, p<0.0001\end{array}$ & & \\
\hline \multicolumn{6}{|c|}{ Previous travel to work injuries $(\mathrm{n})$ : } \\
\hline 0 & 47165 & & & 1.9 & 1.00 \\
\hline 1 & 5570 & & & 3.0 & $2.05(1.72$ to 2.44$)$ \\
\hline 2 & 892 & & & 2.9 & $2.20(1.46$ to 3.33$)$ \\
\hline$\rightarrow 1$ & 169 & & & 3.6 & $\begin{array}{l}3.02(1.46 \text { to } 6.22) \\
\chi_{1}^{2} \text { trend }=62, p<0.0001\end{array}$ \\
\hline \multicolumn{6}{|l|}{ Calendar period: } \\
\hline $1977-80$ & 9140 & 14.5 & 1.00 & 4.1 & 1.00 \\
\hline $1981-84$ & 13920 & 6.4 & $0.62(0.55$ to 0.68$)$ & 2.0 & $0.61(0.50$ to 0.73$)$ \\
\hline $1985-88$ & 15245 & 4.1 & $0.49(0.43$ to 0.55$)$ & 1.7 & $0.62(0.51$ to 0.76$)$ \\
\hline 1989-92 & 15492 & 3.3 & $\begin{array}{l}0.40(0.35 \text { to } 0.46) \\
\chi_{1}^{2} \text { trend }=234, p<0.0001\end{array}$ & 1.1 & $\begin{array}{l}0.43(0.34 \text { to } 0.53) \\
\chi_{1}^{2} \text { trend }=50, p<0.0001\end{array}$ \\
\hline \multicolumn{6}{|l|}{ Job category: } \\
\hline Professionals & 2200 & 0.9 & 1.00 & 0.5 & 1.00 \\
\hline Technicians & 5111 & 2.1 & 2.27 (1.43 to 3.58$)$ & 1.7 & $3.87(1.95$ to 7.67$)$ \\
\hline Support workers & 3729 & 3.1 & $2.89(1.82$ to 4.59$)$ & 2.9 & $5.36(2.66$ to 10.80$)$ \\
\hline Group leaders & 90 & 16.6 & $11.84(6.44$ to 21.76$)$ & 2.2 & $5.47(1.65$ to 18.06$)$ \\
\hline Labourers & 42666 & 7.3 & $\begin{array}{l}6.82(4.43 \text { to } 10.49) \\
\chi_{4}^{2} \text { heterogeneity }=251 \\
\mathrm{p}<0.0001\end{array}$ & 2.0 & $\begin{array}{l}5.16(2.66 \text { to } 9.99) \\
\chi_{4}{ }^{2} \text { heterogeneity }=51 \\
\mathrm{p}<0.0001\end{array}$ \\
\hline \multicolumn{6}{|l|}{ Place of work: } \\
\hline General support services & 4622 & 2.7 & 1.00 & 2.4 & 1.00 \\
\hline Research and production & 5360 & 4.9 & $0.93(0.72$ to 1.22$)$ & 2.5 & $1.11(0.75$ to 1.65$)$ \\
\hline Energy supply & 3721 & 3.8 & $0.58(0.43$ to 0.78$)$ & 1.9 & $0.77(0.50$ to 1.19$)$ \\
\hline Maintenance & 6954 & 6.5 & $0.95(0.73$ to 1.24$)$ & 1.8 & $0.73(0.49$ to 1.11$)$ \\
\hline Cranes, rail, and trucks & 3299 & 6.2 & $0.85(0.64$ to 1.14$)$ & 1.6 & $0.66(0.41$ to 1.05$)$ \\
\hline Plate mill & 14331 & 6.1 & $0.86(0.66$ to 1.12$)$ & 2.0 & $0.81(0.55$ to 1.20$)$ \\
\hline Steel mill and foundry & 7198 & 10.3 & $1.22(0.93$ to 1.59$)$ & 2.2 & $0.83(0.55$ to 1.25$)$ \\
\hline \multirow{2}{*}{$\begin{array}{l}\text { Coke oven and blast } \\
\text { furnace }\end{array}$} & 8312 & 6.6 & $0.92(0.71$ to 1.20$)$ & 1.8 & $0.75(0.50$ to 1.13$)$ \\
\hline & & & $\begin{array}{l}\chi_{7}^{2} \text { heterogeneity }=91 \\
\mathrm{p}<0.0001\end{array}$ & & $\begin{array}{l}\chi_{7}^{2} \text { heterogeneity }=15.9 \\
\mathrm{p}=0.026\end{array}$ \\
\hline Total & 53796 & 6.2 & & 2.0 & \\
\hline
\end{tabular}

^Adjusted for all other variables in the model. 


\section{Discussion}

We found that duration of employment, injury history, calendar period, job category, and area of work were independent risk factors for both workplace and travel to work injury. The rate of travel to work injury also seemed to decrease with age, but age was not an independent predictor of workplace injury when we took into account its strong correlation with duration of employment.

The finding that recently employed workers in a factory meet with more accidents than those who have been employed for longer is a finding that is often mentioned in the safety literature ${ }^{1224}$ and that is confirmed by recent studies. $^{6810}$ These findings, together with the finding that people who are moved from one workplace to another or who act as temporary replacements often meet with accidents, ${ }^{12}$ emphasise the influence of work experience on risk of injury. Lack of experience is a risk factor for injury because it influences the interaction between the person and other workers, familiarity with various occurrences within the job, knowledge of machines and tools in use and their weaknesses or defects, and awareness of surrounding hazards. ${ }^{12} \mathrm{~A}$ further potential explanation for a lower risk of injury among workers employed for longer is selection biasthat is, that workers who encounter an injury might leave employment whereas those who do not have an injury might remain in employment. This seems, however, not to have been the case, mainly because we found that an injury was rarely followed by leaving employment within 2 months.

The decreasing trend in injury rate with calendar period found in this study is in accordance with the trend reported for the country overall by the National Insurance Institute in Brazil. ${ }^{25}$ Likely explanations are changes in the working process - such as better machinery and increased automationintroduction of better safety standards and increased awareness of the burden and cost of injury for the company. One of the main explanations offered for the national trend is the general tendency, in all Brazilian industries, of replacing the permanent workforce with temporary workers contracted from other employers, which has resulted in underreporting of their injuries. ${ }^{26}$ The trend in the present cohort cannot be explained by this phenomenon, however, because subcontracted workers were not included.

A significant increase in the rate of both workplace and travel to work injury was found to be related to the number of injuries of that type previously experienced. The adjusted rate ratios tended to be higher than the crude rate ratios for injury history, because injury history was strongly confounded by the effect of duration of employment and calendar period. The role of injury history as a risk factor for injury has not received much attention in the literature. A study in the manufacturing industry reported that workers with a non-fatal work related injury were more likely to have experienced a previous non-work related injury. ${ }^{27}$ Pilots who were involved in crashes were at increased risk of involvement in future crashes and violations. ${ }^{28}$ For the steel workers, the classification of place of work and job category might be too crude to represent the hazardous jobs at the plant and repeated injuries to the same worker may simply mean that he works on a particularly dangerous part of the production line. On the other hand, safety in the steel industry depends very much on the reaction of the workers to the potential hazards of their environment ${ }^{29}$ and an increased rate relative to injury history might be explained, at least in part, by characteristics of the worker. Reported factors of susceptibility of individual people to occupational injury include age and experience ${ }^{6810}$ as well as the onset of illness, alcoholism, and other substance misuse, and having a hearing defect. ${ }^{12} 30$ Drug use, alcohol ingestion, having a chronic disease $^{31}$ and psychological characteristics ${ }^{32}$ have been associated with injury related to a motor vehicle and having a hearing defect and exposure to occupational noise ${ }^{21}$ with mortality related to a motor vehicle. A very careful investigation of all the factors involved at the time of the accident that caused the injury is needed to identify individual susceptibility to accidents and injury.

Labourers and group leaders were at highest risk of workplace injury. High rates were found in particular in workers at the steel mill and foundry, and to a lesser extent, workers in the coke oven and blast furnace, maintenance unit, plate mill, and in workers responsible for cranes, rail, and trucks. The high rate ratios for these work areas seemed to diminish when adjusted for job category, duration of employment, calendar period, and history of injury. This is likely to be an artefact, however, because job category and work area are both proxies for occupational hazard and the composition of the work force is very dependent on the work area. For example, in the most hazardous places-such as the steel millabout $90 \%$ of the workers are labourers, whereas $60 \%$ of the workers in general support services are support workers. It is likely that our attempt to adjust the work area rate ratios for the effect of job category has resulted in overadjustment for the effect of work area. Our findings (unadjusted for job category) are in accordance with an investigation in steelworks in Mexico, in which the blast furnace area, coke ovens, steel mill, and energy areas were associated with high risks of disabling injury. ${ }^{14}$ Also, an earlier investigation of mortality from injury in the present cohort showed that exposure to noise, heat, dust and fumes, gases and vapours, and being a manual worker were significantly associated with risk of fatal injury. ${ }^{20}$ It has also been reported that prolonged exposure to heat makes workers more susceptible to accidents. ${ }^{33}$ Therefore, preventive efforts need to be focused on these groups with particularly high risk of injury.

Our methodological decision to restrict our investigation of job category and place of work as risk factors to workers who had the same job at the start of employment and end of follow up was necessary because job at the time of injury 
was not known. It might in principle have led to bias, however, because the rates of injury in specific jobs could have been underestimated if workers changed job because of injury. We investigated this by calculating the overall injury rate, weighted for job frequencies, in workers who were relocated and workers who remained in the same job. It seemed that bias had not occurred because the injury rate of workers who were relocated was lower than that of workers who were not.

Travel to work injuries were common among steelworkers. The proportion of travel to work injuries among all occupational injuries $(27.3 \%)$ was much greater than the average in Brazil (3.0\% in 1977 and $6.4 \%$ in 1992). ${ }^{26}$ This discrepancy with national data could be partly explained by the high rate of eye injuries that may be inherent to steelworks, and by the finding that injury related to a motor vehicle is more common among steelworkers. We previously reported that mortalities from injuries related to motor vehicles in this cohort were twice those expected from population rates. ${ }^{19}$ There are also likely to be alternative explanations - such as relative underreporting of travel to work injuries compared with workplace injuries in national registers. Travel to work injury has received little attention in publications and very few studies have investigated a possible role of occupational history.

Although detailed information on travel to work injury was not available, it seems that two main different types of travel to work injuries occurred among the steelworkers; eye injuries most likely caused by emissions from the plant and injuries related to motor vehicles. Nearly half of the travel to work injuries affected the eyes, in $99 \%$ of the cases due to a foreign body. Up to 1982 the industry's chimneys emitted a dense brown smoke containing small fragments of steel which might have injured workers' eyes on the way to work. In accordance with this, more than two thirds of the eye injuries occurred before 1983 when the emissions started to be filtered. This does not, however, explain the decrease in the rate of eye injuries after 1983 and the age dependence, although these might have been partly due to differences in means of transport. The remaining injuries were of types more typical of motor vehicle accidents - such as contusions and lacerations.

Relatively high rates of travel to work injury were found for support workers and labourers. These workers were more likely to travel by bicycle or motorcycle or on foot and as a result were more vulnerable to traffic hazards and emissions by the plant. The rates of injury decreased significantly with age which for motor vehicle accidents might be because of more reckless behaviour among young people ${ }^{34}$ and because older people might use safer vehicles. Preventive programmes in the steel industry could usefully incorporate education on road safety to reduce the burden of these injuries.

Among the steelworkers, eye injuries were also very common in the workplace. About one fifth of the workplace injuries affected the eyes. By comparison, occupational injuries to the eye form about $3 \%-4 \%$ of all industrial injuries. ${ }^{12}$ Exposures to blown sand, coal and iron dusts, and fumes from welding are common to several operations and are associated with a high incidence of foreign bodies in the eye among steelworkers. ${ }^{12}$ These findings warrant investigation of ways to improve eye protection within the plant.

We did not analyse injuries that resulted in lost working days separately because this information was thought to be biased. In Brazil, the first 15 days absence after a worker's injury is paid by the industry and after that by the Ministry of Social Security. The industry pays a special tax to the ministry, that up to 1982 was based on the total days lost from injuries, as a hazard indicator to classify the industry. Therefore, there was a policy to force down the statistics of days lost through injuries in the plant, with the implication that workers were relocated after injury rather than sent home. This is most likely to be the underlying reason for the high median number of lost working days after injuries that we found in this cohort; only workers with very severe injuries were sent home.

This study shows a high frequency of workplace injury among steelworkers and highlights the increased risk among inexperienced workers, workers involved in more hazardous parts of the production process, and workers with a history of work related injury. We also found that travel to work injury was common and that most of these injuries were potentially preventable injuries to the eyes. The study identifies workers who should receive special safety and health training and highlights the need for injury prevention programmes for high risk areas and processes in the steel manufacturing industry to reduce the burden of injury.

The study was only possible because of the full and willing cooperation of the Occupational Health Department of USIMINAS in Brazil. The research project was supported by the International Development Research Centre from Canada.

1 Murray CJ, Lopez AD. Alternative projections of mortality and disability by cause 1990-2020: global burden of disease study. Lancet 1997;349:1498-504

2 Bourbeau R. Analyse comparative de la mortalité violente dans les pays developpés et dans quelques pays en developpement durant la periode 1985-9. World Health Stat $Q$ 1993;46:4-32.

3 National Safety Council. National Safety Council accidents facts (injury statistics). 1998. (www.nsc.org/lrs/statinfo/ af4.htm)

4 Murray CJ, Lopez AD. Global mortality, disability, and the contribution of risk factors: global burden of disease study. Lancet 1997;349:1436-42.

5 Pan American Health Organization. Mortality: trends from 1960 to 1990 and latest data by cause, age, and sex. Washington DC: PAHO, 1992:19-27. (Health Statistics from the Americas, Sci Publ 542.)

6 Warner M, Baker SP, Li G, et al. Acute traumatic injuries in Warner M, Baker SP, Li G, et al. Acute traumatic injuries in
automotive manufacturing. Am $\mathcal{F}$ Ind Med 1998;34:351-8. 7 Aaltonen MV. Occupational injuries in the Finnish furniture industry. Scand $\mathcal{F}$ Work Environ Health 1996;22:197-203.

8 Lowery JT, Borgerding JA, Zhen B, et al. Risk factors for injury among construction workers at Denver International Airport. Am F Ind Med 1998;34:113-20.

9 Kisner SM, Fosbroke DE. Injury hazards in the construction industry. F Occup Med 1994;36:137-43.

10 Sahl JD, Kelsh MA, Haines KD, et al. Acute work injuries among electric utility meter readers. Epidemiology 1997;8: 287-92.

11 McNabb SJ, Ratard RC, Horan JM, et al. Injuries to international petroleum drilling workers, $1988-90$. f Occup Med 1994;36:627-30.

12 International Labour Office. Encyclopaedia of occupational health and safety. Geneva: ILO, 1989.

13 Lloyd JW, Lundin FE, Redmond CK, et al. Long-term mortality study of steelworkers. IV. Mortality by work area. $\mathcal{F}$ Occup Med 1970;12:151-8. 
14 Laurell AC, Nogueira M. Trabajo y salud en SICARTSA. Mexico: Programa de difusion cultural del SITUAM Mexic:

15 Egan-Baum E, Miller BA, Waxweiler RJ. Lung cancer and other mortality patterns among foundrymen. Scand $\mathcal{F}$ Work Environ Health 1981;7(suppl 4):147-55.

16 Decoufle P, Wood DJ. Mortality patterns among workers in a gray iron foundry. Am $\mathcal{F}$ Epidemiol 1979;109:667-75.

17 Koskela RS, Hernberg S, Karava R, et al. A mortality study of foundry workers. Scand $\mathcal{f}$ Work Environ Health 1976;2(suppl 1):73-89.

18 Agrawal OP. Profile of burn injury in steel industry. F Indian Med Assoc 1990;88:4-6.

19 Barreto SM, Swerdlow AJ, Smith PG, et al. Mortality from injuries and other causes in a cohort of 21800 Brazilian steel workers. Occup Environ Med 1996;53:343-50.

20 Barreto SM, Swerdlow AJ, Smith PG, et al. A nested case-control study of fatal work related injury among Bracase-control study of fatal work related injury among Bra-

21 Barreto SM, Swerdlow AJ, Smith PG, et al. Risk of death from motor-vehicle injury in Brazilian steel workers: a from motor-vehicle injury in Brazilian steel workers: a

22 StataCorp Stata statistical sofware: release 5.0. College Station, TX: Stata Corporation, 1997 .

23 Huber PJ. The behavior of maximum likelihood estimates under non-standard conditions. Proceedings of the 5th Berkeley Symposium on Mathematical Statistics and Probability 1967;1:221-33.

24 Heath ED. Identifying those worker populations that are at higher levels of risk. Am Ind Hyg Assoc F 1991;52:A221-2.
25 Alves S, Luchesi G. Acidentes de trabalho e doenças profissionais no Brasil- a precariedade das informações. Informe sionais no Brasil- a precariedade das
epidemiologico do SUS 1992:3:7-19.

26 Wünsch Filho V. Variações e tendências na morbimortalidade dos trabalhadores. In: Monteiro CA. Velhos e Novos Males da saúde no Brasil: a evolução do país e de suas doenças. Ed. São Paulo: HUCITEC, NUPENS/USP, 1996: 289-330.

27 Tsai, SP, Bernacki EJ, Dowd CM. The relationship between work-related and non-work-related injuries. $\mathcal{f}$ Community Health 1991;16:205-12.

$28 \mathrm{Li} \mathrm{G}$, Baker SP. Crash and violation experience of pilots involved in prior commuter and air taxi crashes: a historical cohort study. Aviat Space Environ Med 1995;66:1131-5.

29 International Labour Office. Encyclopaedia of occupational health and safety. Geneva: ILO, 1998.

30 Pollack ES, Franklin GM, Fulton-Kehoe D, et al. Risk of jobrelated injury among construction laborers with a diagnosis of substance abuse. F Occup Environ Med 1998;40:573-7.

31 Chipman ML. Risk factors for injury: similarities and differences for traffic crashes and other causes. Accid Anal Prev 1995;27:699-706.

32 Jin HQ, Araki S, Wu XK, et al. Psychological performance of accident-prone automobile drivers in China: a case-control accident-prone automobile drivers in

33 Dukes-Dobos FN. Hazards of heat exposure. A review. Scand f Work Environ Health 1981;7:73-83.

34 Rutter DR, Quine L. Age and experience in motorcycling safety. Accid Anal Prev 1996;28:15-21.

\section{Correspondence and editorials}

Occupational and Environmental Medicine welcomes correspondence relating to any of the material appearing in the journal. Results from preliminary or small scale studies may also be published in the correspondence column if this seems appropriate. Letters should be not more than 500 words in length and contain a minimum of references. Tables and figures should be kept to an absolute minimum. Letters are accepted on the understanding that they be subject to editorial revision and shortening.

The journal also publishes editorials which are normally specially commissioned. The Editor welcomes suggestions regarding suitable topics; those wishing to submit an editorial, however, should do so only after discussion with the Editor. 